\title{
Adaptability and Forage Characterization of Finger Millet Accessions in U.S. Southern Great Plains
}

\author{
Gurjinder S. Baath ${ }^{1, *}$, Brian K. Northup ${ }^{2}$, Prasanna H. Gowda ${ }^{2}$, Alexandre C. Rocateli ${ }^{1}$ \\ and Kenneth E. Turner ${ }^{2}$ \\ 1 Department of Plant and Soil Sciences, Oklahoma State University, 371 Agricultural Hall, \\ Stillwater, OK 74078, USA; alex.rocateli@okstate.edu \\ 2 Grazinglands Research Laboratory, United States Department of Agriculture (USDA), Agricultural Research \\ Service (ARS), 7207 West Cheyenne St., El Reno, OK 73036, USA; brian.northup@ars.usda.gov (B.K.N.); \\ prasanna.gowda@ars.usda.gov (P.H.G.); ken.turner@ars.usda.gov (K.E.T.) \\ * Correspondence: gbaath@okstate.edu; Tel: +1-575-642-8027
}

Received: 10 August 2018; Accepted: 7 September 2018; Published: 10 September 2018

check for updates

\begin{abstract}
Low forage quality of available perennial warm-season grasses during mid-summer through late summer affects the production of stocker cattle in the U.S. Southern Great Plains (SGP). Finger millet (Eleusine coracana Gaertn L.), which is a drought tolerant annual grass, could be a promising forage for the SGP. This field study assessed the adaptability and forage characteristics of 11 finger millet accessions originally sourced (1964-1981) from different parts of the world. Results of this study suggested that finger millet can generate forage yields ranging from 5.0 to $12.3 \mathrm{Mg}$ $\mathrm{ha}^{-1} 165$ days after planting. Finger millet forage contained 105 to $156 \mathrm{~g} \mathrm{~kg}^{-1}$ crude protein, 598 to $734 \mathrm{~g} \mathrm{~kg}^{-1}$ neutral detergent fiber, 268 to $382 \mathrm{~g} \mathrm{~kg}^{-1}$ acid detergent fiber, 597 to $730 \mathrm{~g} \mathrm{~kg}^{-1}$ in vitro true digestibility, and 387 to $552 \mathrm{~g} \mathrm{~kg}^{-1}$ neutral detergent fiber digestibility. Ten of the 11 accessions flowered and produced grains with yields varying from 60 to $1636 \mathrm{~kg} \mathrm{ha}^{-1}$. Overall, finger millet has the potential to serve as an alternative crop for the production of forage and possibly grain in the SGP. Further research needs to be focused on developing strategies for agronomic management and evaluating the capacity of finger millet under different grazing and hay production settings in the SGP.
\end{abstract}

Keywords: drought tolerance; forage quality; forage yield; grain production; stocker cattle

\section{Introduction}

Winter wheat (Triticum aestivum L.) based production systems are the primary choices of producers in the U.S. Southern Great Plains (SGP). An average of 2.06 million ha was planted annually in Oklahoma between 2013 to 2017 [1]. Most of the winter wheat is conventionally tilled and grown in continuous rotations and separated by periods of summer fallow under rain fed conditions. Winter wheat is grown to produce grain, forage, or forage-grain combinations of products $[2,3]$. Summer fallow from June to September is considered a conservative technique that helps to store moisture for the following wheat crop. However, the winter wheat-summer fallow system has various concerns pertaining to sustainability such as the presence of low amounts of forage before and after available wheat paddocks [4], low efficiency in the usage of precipitation and available soil water by wheat-summer fallow systems [5], increased vulnerability to soil erosion through conventional tillage, and reduced amounts of organic nitrogen and carbon in soils [6].

Grazing low-cost pastures to generate gain by yearling stocker cattle is an important component of agriculture in the SGP [7,8] and a key strategic feature of the beef production system of the United States [9]. Stocker cattle in the region rely on wheat pasture from winter through spring and 
pastures of introduced perennial warm-season grasses such as old world bluestems (Bothriochloa spp.) and bermudagrass [Cynodon dactylon (L.) Pers.] for late spring and summer grazing [7]. However, high quality forage becomes unavailable during July through late September as the amount of high quality biomass provided by these perennial grasses declines. There has been a continual search for alternative crops with the capacity to act as cover and produce quality forage during the late summer. Past research has focused on defining the potential of grain legumes (pulses) as forage $[9,10]$. Many of the studies reported the aboveground biomass of most pulses possessed large proportions of low digestible stems, which could be a limitation in grazing applications [4,11-16]. Therefore, further exploration of other species of grasses and legumes that may function as summer crops needs investigation to enhance the sustainability of forage-stocker production systems of the SGP.

Finger millet (Eleusine coracana Gaertn L.) is an annual grass, which is native to the Ethiopian and African highlands and widely adapted to a range of different growing conditions. Finger millet is an important cereal crop in many drought-prone regions across the world [17]. Its primary growing area ranges from $20^{\circ} \mathrm{N}$ to $20^{\circ} \mathrm{S}$ in the semiarid to the arid tropics even though finger millet is grown in areas at $30^{\circ} \mathrm{N}$ (Himalayan regions of India and Nepal). A minimum temperature of 8 to $10^{\circ} \mathrm{C}$ is needed for germination and warm conditions involving an average temperature of 26 to $29^{\circ} \mathrm{C}$, which leads to its optimal growth [18]. Finger millet yields about 1 to $1.5 \mathrm{Mg} \mathrm{ha}^{-1}$ grain and 3 to $9 \mathrm{Mg} \mathrm{ha}^{-1}$ fodder under dryland conditions in India [18]. It also has a high water use efficiency and consumes $10 \%$ to $20 \%$ less water than sorghum [Sorghum bicolor (L.) Moench] under irrigated conditions [19]. Finger millet can tolerate some degree of waterlogging or salinity, but it is sensitive to frost [20].

Finger millet has served as a safeguard against malnutrition during the drought and is a staple food in some regions of India as well as Eastern and Central Africa [21]. It is utilized in many ways including bread, porridge, malt, popped products and in both alcoholic and non-alcoholic brewing industries [22]. The seed of finger millet contains $7-14 \%$ protein, $73 \%$ carbohydrate, $1.5 \%$ fat, and $3.6 \%$ fiber. The seed is also higher in $\mathrm{Ca}, \mathrm{P}, \mathrm{Fe}$, and $\mathrm{Mn}$ than other cereal grains and is considered an ideal food for breastfeeding mothers, growing children, and the infirmed [23]. It was found out to be useful in controlling blood glucose levels, which is recommended for diabetic patients [24]. Moreover, finger millet seed does not possess gluten and is considered ideal for celiac patients [25].

Forage produced by finger millet is highly nutritious and fed to livestock in several African and Asian countries. Nutrient concentrations of crude protein (CP; $10.7 \%), \mathrm{Ca}(1.20 \%), \mathrm{P}(0.44 \%), \mathrm{K}(4.53 \%)$, and $\mathrm{Mg}(0.31 \%)$ levels were reported in the biomass of four finger millet accessions grown in the semi-arid Texas High Plains that were higher than forage corn (Zea mays L.) and forage sorghum [26].

Despite its several beneficial traits, lack of scientific research evaluating finger millet potential as a grain or forage crop limits its adoption worldwide. Most of the available research findings are derived from India, which was primarily aimed at the nutritional properties of finger millet grain compared to other crops. In the U.S., promising forage quality results were observed when testing five accessions of finger millet under irrigated conditions in the Southern High Plains [26]. However, other researchers observed restricted grain production due to the finger millet photoperiod sensitivity in central California and the Texas Panhandle [23]. This issue might be true to the SGP, which make photo-insensitive varieties the best alternative to the region. Consequently, there is a fundamental need to evaluate photo-insensitive varieties to determine their climate adaptability, drought tolerance, yield capabilities, and nutritious value in order to assess the potential of finger millets as summer forage for the SGP. The specific objectives of this study were to: (1) assess the adaptability of 11 finger millet accessions to summer conditions of the SGP and (2) define their capabilities as a summer forage crop.

\section{Materials and Methods}

This study was carried out at the USDA-ARS Grazinglands Research Laboratory $\left(35{ }^{\circ} \mathrm{N}\right.$, $98^{\circ} \mathrm{W}$, elevation $414 \mathrm{~m}$ ) near El Reno, OK in 2017. For this study, 11 accessions of finger millet (250 seeds/accession) were collected from the USDA-ARS Plant Genetic Resources Conservation Unit, 
Griffin, GA (Table 1). These accessions were sown on 20 April into germinating trays $(56 \times 28 \times 6 \mathrm{~cm})$ with a Canadian sphagnum peat moss based mixture and kept in a greenhouse at $25{ }^{\circ} \mathrm{C} / 20^{\circ} \mathrm{C}$ (day/night) with regular irrigation for five weeks. The purpose of maintaining plants in the greenhouse was to ensure maximum germination and establishment due to the limited number of seeds available per accession.

Table 1. Characteristics of 10 finger millet accessions obtained from USDA-ARS Plant Genetic Resources Conservation Unit, which is described by the Germplasm Resources Information Network (GRIN).

\begin{tabular}{lccccccc}
\hline GRIN ID & Location & Latitude $\left({ }^{\circ} \mathbf{N}\right)$ & $\begin{array}{c}\text { Maturity } \\
\text { (Days) }\end{array}$ & $\begin{array}{c}\text { Plant } \\
\text { Height }(\mathbf{m})\end{array}$ & $\begin{array}{c}\text { Foliage } \\
\text { Amount }\end{array}$ & $\begin{array}{c}\text { Seed } \\
\text { Production }\end{array}$ & $\begin{array}{c}\text { Received } \\
\text { (Year) }^{2}\end{array}$ \\
\hline PI 302662 & India & 31.10 & 108 & 0.9 & Medium & Medium & 1964 \\
PI 315700 & South Africa & -25.73 & 106 & 0.3 & Abundant & Medium & 1966 \\
PI 321083 & Kenya & -0.09 & 121 & 1.1 & Abundant & Medium & 1967 \\
PI 321126 & Uganda & 0.61 & 110 & 1.4 & Abundant & Medium & 1967 \\
PI 462414 & India & 22.98 & 112 & 0.8 & Medium & Abundant & 1981 \\
PI 462417 & India & 22.98 & 77 & 0.5 & Medium & Abundant & 1981 \\
PI 462442 & India & 25.09 & 87 & 0.3 & Medium & Abundant & 1981 \\
PI 462638 & India & 12.29 & 115 & 1.0 & Medium & Abundant & 1981 \\
PI 462943 & Uganda & 1.37 & 122 & 0.5 & Medium & Medium & 1981 \\
PI 463012 & India & NA ${ }^{1}$ & 148 & 0.9 & Medium & Medium & 1981 \\
PI 463041 & India & NA $^{1}$ & 127 & 1.2 & Abundant & Abundant & 1981 \\
\hline
\end{tabular}

Seedlings were hand transplanted on 25 May into a field plot, which was disked twice, rototilled, and culti-packed prior to transplanting. The soils on the experiment field were characterized as Brewer silty clay loams (fine, mixed, superactive, thermic Udertic Argiustolls) with a $\mathrm{pH}$ of $6.9,0 \%$ to $1 \%$ slope, low water permeability $\left(0.2-1.5 \mathrm{~cm} \mathrm{~h}^{-1}\right)$, moderately well drained, and rarely flooded [27]. Prior to this study, the site was managed through conventional tillage and used for growing wheat as a cover crop during the previous 10 years.

Each accession was assigned to three replicate experimental plots, which consisted of single 15 -m length rows spaced $60 \mathrm{~cm}$ apart with $\sim 30 \mathrm{~cm}$ spacing between individual plants. About $50 \mathrm{~mm}$ total water was applied in three irrigations on alternate days with a sprinkler system to ensure good establishment of seedlings after transplanting (Figure 1). Urea (46-0-0) was applied at the rate of $100 \mathrm{~kg} \mathrm{ha}^{-1}$ to ensure no $\mathrm{N}$ limitations for the crop 30 days after transplanting. Broadleaf weeds were controlled by application of 2,4-Dichlorophenoxyacetic acid herbicide and grass weeds were hand weeded 30 days after transplanting.

The agronomic management of finger millet in this study is similar to techniques used to grow finger millet for grain in India and Africa [26]. In these regions, seeds are broadcast into nursery beds and watered for 21 to 30 days to ensure seedling growth. Thereafter, seedlings are transplanted into $0.6 \mathrm{~m}$ to $1.0 \mathrm{~m}$ spaced rows in widely spaced (up to $30 \mathrm{~cm}$ ) clumps (three to six plants per clump) within rows and irrigated after transplanting and as needed during growing seasons. Our use of a similar approach (wide rows and widely spaced plants) allowed some comparison of responses of accessions to results from earlier studies [26]. This approach also allowed for the optimum use of the limited amounts of seed available ( $n=250$ per accession) in order to define the capacity of tested accessions to produce both forage and grain in the SGP.

Harvesting of accessions was done 130 days after transplanting prior to the occurrence of the first potential freeze for the experimental site [27]. Before harvesting, canopy height was measured from the soil surface to the top of the spikelet for each accession. Samples of aboveground biomass were collected by clipping $0.5-\mathrm{m}$ row lengths from each plot. All whole biomass samples were dried to a constant weight in a forced-air oven at $60^{\circ} \mathrm{C}$ and their dry weights were recorded. Grain yield was obtained by separating spikelets from each sample, which was followed by threshing and cleaning grains using a column blower. Each whole biomass sample (including grains and chaff) was ground to pass a 2-mm screen in a Wiley mill for forage quality analyses. Total $\mathrm{N}$ concentrations were determined 
by analyzing gases evolved after flash combustion of samples in an auto-analyzer (Model Vario Macro, Elementar Ameericas, Inc., Mt. Laurel, NJ, USA) and multiplied with a factor of 6.25 to calculate CP. The fractions of neutral detergent fiber (NDF) and acid detergent fiber (ADF) in forage samples were obtained by procedures outlined for a batch fiber analyzer (ANKOM Technology, Macedon, NY, USA). In vitro true digestibility (IVTD) was determined by using procedures for a Daisy Digester (ANKOM Technology, Macedon, NY, USA). Neutral detergent fiber digestibility (NDFD) was calculated by using the equation: $\mathrm{NDFD}=[1-\{(100-\mathrm{IVTD}) / \mathrm{NDF}\}] \times 100$ [28].

Data collected were analyzed by completely randomized design with three replicate sampled plots for each accession of finger millet. One-way analyses of variance (ANOVA) was performed on canopy height, dry biomass, grain yield, CP, NDF, ADF, IVTD, and NDFD using PROC GLM in SAS version 9.4 to identify the differences among accessions [29]. Differences among the means were evaluated by the Least Significance Difference (LSD) test at a 5\% significance level [30].

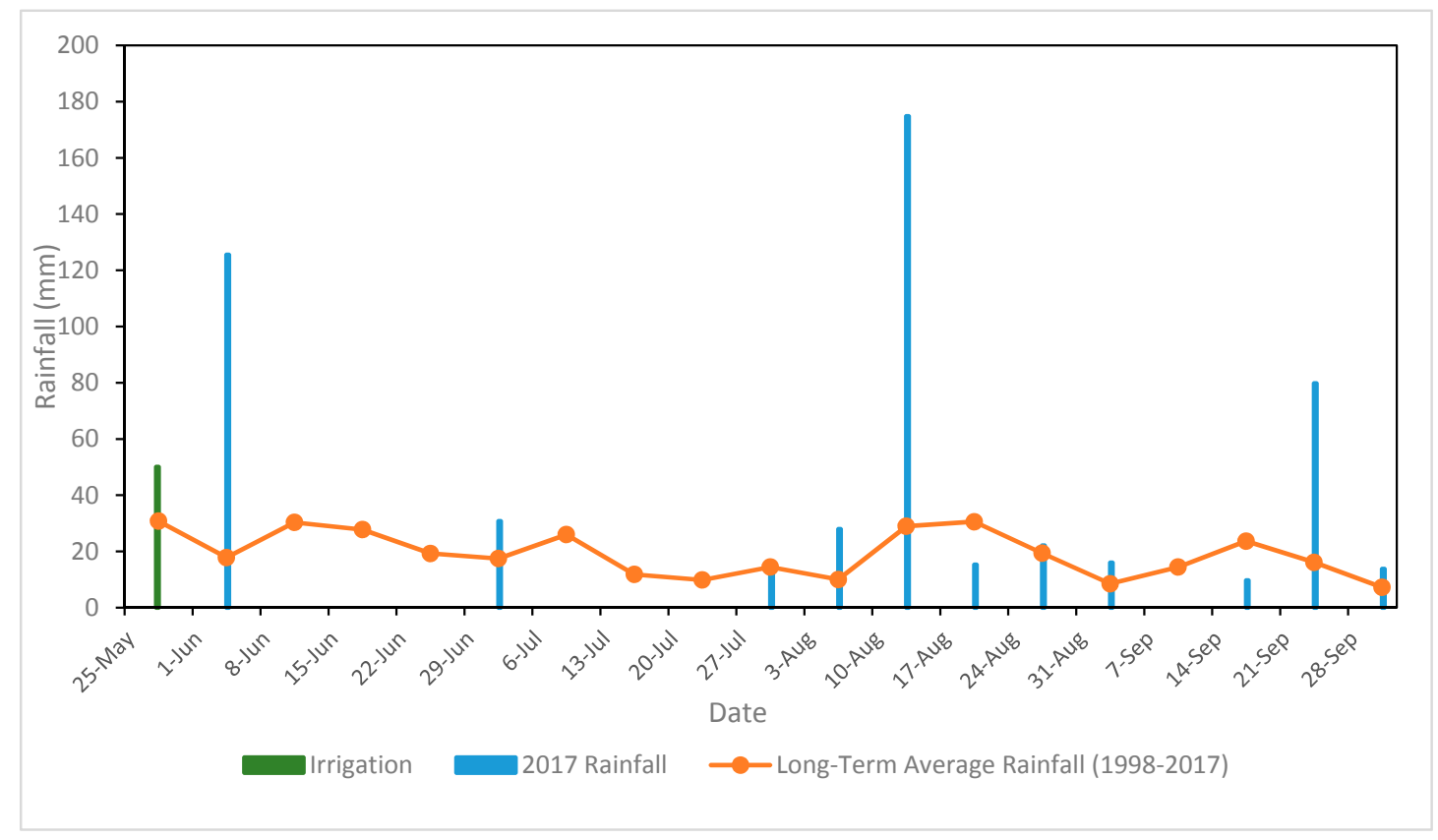

Figure 1. Weekly irrigation and rainfall received during the summer growing season of 2017 and the long-term trend in the average rainfall (1998-2017) at El Reno, OK.

\section{Results and Discussion}

\subsection{Adaptability}

All finger millet accessions showed excellent emergence (>90\%) despite some seeds being in storage for 36 to 53 years (Table 1). Hence, finger millet seeds are capable of sustaining their germinability if held in storage for long periods of time. Finger millet seedlings showed good germination and establishment in the field after receiving three light irrigations in the first week and $120 \mathrm{~mm}$ rainfall in the second week after transplanting (Figure 1). However, a prolonged drought occurred afterward and only $30 \mathrm{~mm}$ of rain was received in the next seven weeks of June to July. All finger millet accessions exhibited moderate growth during the dry period and generated sufficient amounts of forage in response to precipitation that was received during the rest of the growing season. Average daily maximum temperature (Tmax) of $31^{\circ} \mathrm{C}$ and minimum temperature (Tmin) of $18{ }^{\circ} \mathrm{C}$ were encountered during the growing season (Figure 2). Since finger millet is a short-day plant requiring an optimum photoperiod of $12 \mathrm{~h} \mathrm{[23],} \mathrm{the} \mathrm{possibility} \mathrm{of} \mathrm{flowering} \mathrm{and} \mathrm{grain} \mathrm{formation} \mathrm{during} \mathrm{summers}$ was not expected due to longer day lengths (about $14 \mathrm{~h}$ ). However, in this study, all of the finger millet accessions flowered and attained physiological maturity within 90 to 120 days after transplanting 
except PI 315700. In this study, the failure to flower by this accession was apparently related to its photoperiod sensitivity and source from a higher latitude (Table 1).

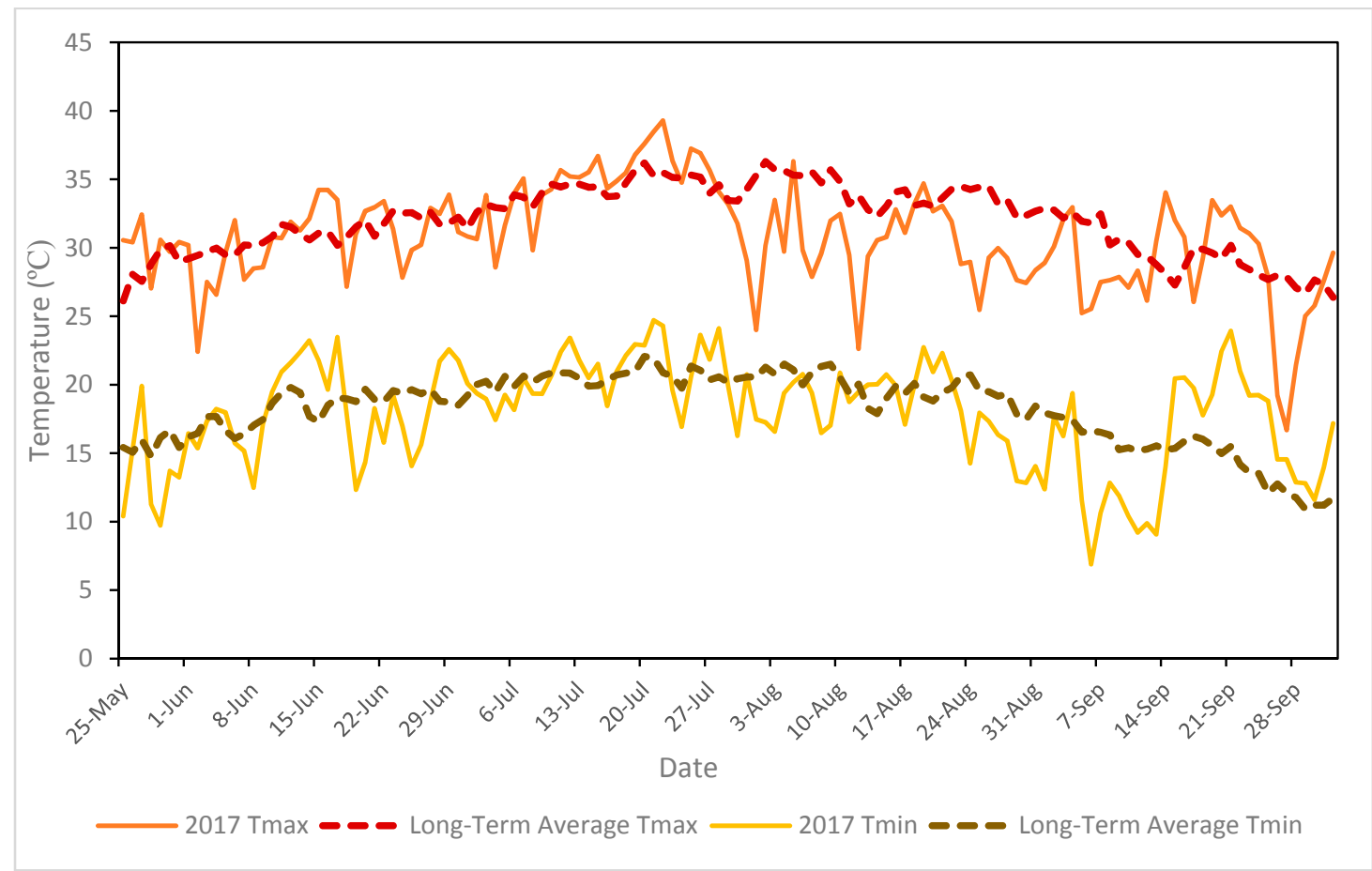

Figure 2. Daily temperature recorded during the summer growing season of 2017 and long-term averages (1998-2017) at El Reno, OK. Tmax and Tmin indicate the daily maximum and daily minimum temperatures, respectively.

\subsection{Canopy Height}

The canopy height of 11 finger millet accessions varied from 23 to $94 \mathrm{~cm}$ (Table 2). The PI 462638 line showed maximum canopy height among the finger millets while the minimum height was noticed in PI 315700, which had a spreading type growth form. Both growth forms for these accessions were in agreement with the GRIN database (Tables 1 and 2). In general, canopy heights of PI 462417, PI 462442, and PI 462943 were greater than those given in the GRIN database. Alternatively, PI 321083, PI 463041, PI 462414, PI 302662, and PI 321126 had shorter heights than the GRIN values (Tables 1 and 2).

\subsection{Grain Yield}

Different accessions tested achieved grain yields that ranged from 60 to $1636 \mathrm{~kg} \mathrm{ha}^{-1}$ during the summer in response to a common set of conditions (location, environment, soil fertility, row spacing, plant spacing, fertilizer level, Table 2). The PI 302662 showed higher grain yields followed by PI 462414 and PI 262442 while the lowest grain yields were observed for PI 321126 and PI 462417. Grain yields of PI 321083, PI 462442, and PI 462414 matched the information stated by GRIN while PI 462417, PI 463041, PI 462943, PI 462638, PI 321126, and PI 463012 were lower than the expected grain production scale of GRIN. In forage-livestock systems of the SGP, grain production of finger millet would not likely to play an important role. However, producers would need a seed source for planting if the finger millet is to be a valid forage resource for this region. Growing varieties with a capacity for seed production would allow the use of the finger millet in the SGP region and perhaps result in an enhanced efficiency of farming operations. Moreover, with the continuously increasing human population and demand for cereal grains, the grain-producing capacity of an accession used in the region may provide an opportunity for SGP producers to meet such future demands. 
Table 2. Canopy height, total dry biomass, and grain yield of 11 accessions of finger millet at 165 days after planting when all accessions had completed reproduction at El Reno, OK.

\begin{tabular}{cccc}
\hline GRIN ID & Canopy Height (cm) & Total Dry Biomass $\mathbf{( \mathbf { M g ~ h a } ^ { - \mathbf { 1 } } )}$ & Grain Yield $\mathbf{( k g ~ h a}^{\mathbf{- 1}} \mathbf{~}$ \\
\hline PI 302662 & $77.0 \mathrm{c}$ & $10.53 \mathrm{~b}$ & $1636.2 \mathrm{a}$ \\
PI 315700 & $23.7 \mathrm{f}$ & $5.23 \mathrm{de}$ & - \\
PI 321083 & $75.9 \mathrm{c}$ & $10.22 \mathrm{~b}$ & $898.6 \mathrm{~d}$ \\
PI 321126 & $81.3 \mathrm{c}$ & $6.73 \mathrm{~cd}$ & $60.2 \mathrm{~g}$ \\
PI 462414 & $57.0 \mathrm{e}$ & $7.40 \mathrm{c}$ & $1400.5 \mathrm{~b}$ \\
PI 462417 & $63.0 \mathrm{~d}$ & $5.02 \mathrm{e}$ & $233.6 \mathrm{fg}$ \\
PI 462442 & $61.7 \mathrm{de}$ & $5.40 \mathrm{de}$ & $1187.0 \mathrm{bc}$ \\
PI 462638 & $94.1 \mathrm{a}$ & $12.35 \mathrm{a}$ & $1035.9 \mathrm{~cd}$ \\
PI 462943 & $66.7 \mathrm{~d}$ & $6.48 \mathrm{cde}$ & $481.2 \mathrm{e}$ \\
PI 463012 & $87.4 \mathrm{~b}$ & $6.46 \mathrm{cde}$ & $313.9 \mathrm{ef}$ \\
PI 463041 & $81.6 \mathrm{bc}$ & $6.93 \mathrm{c}$ & $392.5 \mathrm{ef}$ \\
\hline$p$-value & $<0.0001$ & $<0.0001$ & $<0.0001$ \\
LSD $(0.05)$ & 5.7 & 1.50 & 233.9 \\
\hline
\end{tabular}

Data are means of three replicates. Values within each column followed by the same letter(s) are not different according to the least significance difference (LSD) test $(p \leq 0.05)$. NS $=$ Non-significant at $p=0.05$.

\subsection{Forage Yield}

The total dry biomass (including grain and chaff) produced by the finger millet accessions ranged between 5.0 to $12.3 \mathrm{Mg} \mathrm{ha}^{-1}$ (Table 2). The greatest forage production was observed with PI 462638, which also achieved the tallest canopy height. In comparison, PI 462417, PI 315700, PI 462442, PI 462943, and PI 463012 showed lower forage production. The amount of forage produced by PI 302662 and PI 462638 was above the level stated by GRIN while forage produced by PI 463041, PI 321126, and PI 315700 was below the expected levels. Forage production by all remaining PI were in agreement with the GRIN database (Tables 1 and 2). Overall, the quantity of forage produced by all finger millet accessions was above the level $\left(1.1 \mathrm{Mg} \mathrm{ha}^{-1}\right)$ needed to avoid limitations on grazing by cattle due to forage availability [31].

\subsection{Nutritive Value of Forage}

The $\mathrm{CP}, \mathrm{NDF}, \mathrm{ADF}$, and IVTD concentrations differed among the 11 finger millet accessions (Table 3). The CP content of finger millet accessions at 165 days after planting ranged from 105 to $156 \mathrm{~g} \mathrm{~kg}^{-1}$. The highest concentrations of CP (130-156 g kg-1) were observed in PI 462417, PI 462442, PI 321083, PI 462414, and PI 462943. CP was comparatively lower (105-126 g kg-1) in the six remaining lines. The NDF concentration of the tested accessions ranged between 598 to $734 \mathrm{~g} \mathrm{~kg}^{-1}$ (Table 3). The PI 321126 had the lowest NDF concentration, but was only different from PI 315700 , PI 462638, PI 302662, and PI 462442. The ADF concentration of finger millet accessions varied from 268 to $382 \mathrm{~g} \mathrm{~kg}^{-1}$ (Table 3). The lowest ADF concentration was observed in PI 462943, which was not different from those of PI 321083, PI 463041, PI 321126, and PI 463012. The IVTD of the accessions ranged between 597 to $730 \mathrm{~g} \mathrm{~kg}^{-1}$ (Table 3). The higher IVTD concentrations $\left(686-730 \mathrm{~g} \mathrm{~kg}^{-1}\right.$ ) were observed in PI 462943, PI 321126, PI 463012, and PI 321083 in comparison to the other seven finger millet lines. The NDFD of tested accessions varied from 387 to $552 \mathrm{~g} \mathrm{~kg}^{-1}$ (Table 3). PI $462943 \mathrm{had}$ the greatest amount of digestible NDF even though it was similar to those of PI 315700, PI 321083, PI 321126, PI 463012, and PI 463041. NDFD content is directly associated with the forage intake by cattle and a one-unit increase in NDFD, which leads to a $0.17 \mathrm{~kg} /$ day increase in dry matter intake [32]. It appeared that leaving the early maturing accessions in the field until harvest did not have a great effect on deterioration of dry matter or nutritive value. Consequently, the finger millet could be left as standing forage until frost for grazing as needed based on the depletion of other pastures. 
Table 3. Forage nutritive value of whole plant biomass of 11 accessions of finger millet 165 days after planting when all accessions had completed reproduction at El Reno, OK.

\begin{tabular}{cccccc}
\hline GRIN ID & CP & NDF & ADF & IVTD & NDFD \\
\hline \multicolumn{5}{c}{ g kg $^{-1}$} \\
PI 302662 & $118.5 \mathrm{~cd}$ & $675.2 \mathrm{~b}$ & $366.6 \mathrm{ab}$ & $596.8 \mathrm{f}$ & $402.2 \mathrm{de}$ \\
PI 315700 & $105.5 \mathrm{~d}$ & $733.9 \mathrm{a}$ & $382.3 \mathrm{a}$ & $648.1 \mathrm{cde}$ & $520.1 \mathrm{ab}$ \\
PI 321083 & $144.8 \mathrm{abc}$ & $613.0 \mathrm{de}$ & $294.2 \mathrm{def}$ & $685.7 \mathrm{abc}$ & $486.7 \mathrm{abc}$ \\
PI 321126 & $126.6 \mathrm{bcd}$ & $597.8 \mathrm{e}$ & $284.9 \mathrm{ef}$ & $701.3 \mathrm{ab}$ & $499.4 \mathrm{abc}$ \\
PI 462414 & $136.6 \mathrm{abc}$ & $641.2 \mathrm{bcde}$ & $335.9 \mathrm{bcd}$ & $631.3 \mathrm{def}$ & $423.1 \mathrm{cde}$ \\
PI 462417 & $156.4 \mathrm{a}$ & $634.7 \mathrm{bcde}$ & $340.5 \mathrm{abc}$ & $611.7 \mathrm{ef}$ & $387.4 \mathrm{e}$ \\
PI 462442 & $149.4 \mathrm{ab}$ & $657.4 \mathrm{bcd}$ & $353.8 \mathrm{ab}$ & $635.9 \mathrm{def}$ & $445.6 \mathrm{bcde}$ \\
PI 462638 & $121.3 \mathrm{bcd}$ & $670.0 \mathrm{bc}$ & $327.3 \mathrm{bcde}$ & $637.0 \mathrm{def}$ & $455.5 \mathrm{bcde}$ \\
PI 462943 & $130.3 \mathrm{acbd}$ & $600.6 \mathrm{e}$ & $268.4 \mathrm{f}$ & $730.5 \mathrm{a}$ & $551.8 \mathrm{a}$ \\
PI 463012 & $118.1 \mathrm{~cd}$ & $607.1 \mathrm{de}$ & $291.6 \mathrm{def}$ & $691.8 \mathrm{abc}$ & $493.3 \mathrm{abc}$ \\
PI 463041 & $119.3 \mathrm{~cd}$ & $620.0 \mathrm{cde}$ & $299.7 \mathrm{cdef}$ & $675.4 \mathrm{bcd}$ & $476.6 \mathrm{abcd}$ \\
\hline$p$-value & 0.0398 & 0.0003 & 0.0003 & $<0.0001$ & 0.0102 \\
LSD (0.05) & 29.2 & 50.4 & 44.7 & 45.4 & 81.8 \\
\hline
\end{tabular}

Data are the means of three replicates. Values within each column followed by the same letter(s) are not different, according to the least significance difference (LSD) test $(p \leq 0.05)$. NS $=$ Non-significant at $p=0.05$.

Overall, PI 321083, PI 321126, and PI 462938 may be the three best candidates among the tested accessions for the SGP since these lines were able to produce 7.4 to $12.3 \mathrm{Mg} \mathrm{ha}^{-1}$ forage and grain yields of 897 to $1400 \mathrm{~kg} \mathrm{ha}^{-1}$. A general comparison of several forage nutritive value parameters from these three accessions with generalized attributes of bermudagrass and old world bluestem from other studies in Oklahoma is given in Table 4. However, soil and weather conditions varied among these and the current study. Therefore, some caution is required in these comparisons. The forage of finger millet at 165 days after planting appears superior to foraging both bermudagrass and old world bluestem in $\mathrm{CP}, \mathrm{NDF}$, and ADF. Therefore, finger millet has the potential to produce quality summer forage compared to the perennial warm-season grasses traditionally used as summer forage in the SGP.

Table 4. Comparisons of forage nutritive value parameters of finger millet, bermudagrass, and old world bluestem.

\begin{tabular}{ccccc}
\hline Species & CP & NDF & ADF & Citation \\
\hline \multicolumn{5}{c}{$\mathbf{g ~ k g}^{-1}$} \\
Finger millet & $134 \pm 24$ & $641 \pm 42$ & $319 \pm 37$ & \\
Bermudagrass & $84 \pm 29$ & $716 \pm 29$ & $337 \pm 22$ & {$[33]$} \\
Old world bluestem & $128 \pm 25$ & $821 \pm 36$ & $471 \pm 27$ & {$[34]$} \\
\hline
\end{tabular}

While finger millet shows a degree of capacity to grow in the SGP, there are issues to be addressed before its use in the region especially the development of management strategies. There is little information regarding the optimal combination of row spacing, the amounts of fertilizers, and water availability for the use of finger millet as both forage and grain crop in the SGP. The current limited availability of seed for the accessions tested here also means there is a need for a seed increase to test the effects of different agronomic factors related to using finger millet as a forage crop at the plot scale. Furthermore, there is a need for information on the growth responses of finger millet in different soils of the region. The small seed size $(1.3$ to $1.6 \mathrm{~mm})$ of finger millet also presents challenges for identifying the best technology for planting. Such issues must be addressed for the application of finger millet in larger, production-scale settings for hay production and grazing in the SGP. 


\section{Conclusions}

Finger millet accessions sourced from different geographic locations exhibited a range of adaptation regarding the summer conditions of the SGP. All finger millet lines tolerated the June to July hot and dry period and produced sufficient amounts of forage in response to precipitation that occurred during the rest of the growing season. All finger millet accessions except PI 315700, which originated from South Africa, flowered and generated a wide range of grain yields. This has not been previously reported for the U.S. within the existing literature. The grain-producing capability of finger millet may allow SGP producers to meet demands of gluten-free human food in the United States. Finger millet forage possessed sufficient amounts of crude protein, lower fiber concentrations, and higher digestibility 165 days after planting than the traditional warm-season perennial grasses used for graze stocker cattle, which indicates its potential for use in forage-livestock systems during the summer in the SGP. Future research should focus on developing strategies for agronomic management and evaluating its capability in grazing and hay production systems for beef cattle.

Author Contributions: G.S.B., B.K.N., P.H.G., and A.C.R. designed the experiment. G.S.B. and B.K.N. performed the experiment. K.E.T. contributed materials/analysis. G.S.B., B.K.N., P.H.G., and A.C.R. wrote the paper.

Acknowledgments: The authors would like to recognize ARS technicians Kory Bollinger, Jeff Weik, and Cindy Coy for their assistance in managing experimental sites, collecting, processing, and analyzing samples.

Conflicts of Interest: The authors declare no conflicts of interest.

Disclaimer: Mention of trade names or commercial products in this publication is solely for the purpose of providing specific information and does not imply recommendation or endorsement by the U.S. Department of Agriculture. USDA is an equal opportunity provider and employer.

\section{References}

1. United States Department of Agriculture. National Agricultural Statistics Service. 2017. Available online: https:/ / www.nass.usda.gov/.

2. Decker, J.E.; Epplin, F.M.; Morley, D.L.; Peeper, T.F. Economics of five wheat production systems with no-till and conventional tillage. Agron. J. 2009, 101, 364-372. [CrossRef]

3. Edwards, J.T.; Carver, B.F.; Horn, G.W.; Payton, M.E. Impact of dual-purpose management on wheat grain yield. Crop Sci. 2011, 51, 2181-2185. [CrossRef]

4. Northup, B.K.; Rao, S.C. Green manure and forage potential of lablab in the US southern Plains. Agron. J. 2015, 107, 1113-1118. [CrossRef]

5. Patrignani, A.; Lollato, R.P.; Ochsner, T.E.; Godsey, C.B.; Edwards, J.T. Yield gap and production gap of rainfed winter wheat in the southern Great Plains. Agron. J. 2014, 106, 1329-1339. [CrossRef]

6. Kelley, K.W.; Sweeney, D.W. Long-term Crop Rotation and Tillage Affects Wheat and Double-crop Soybean and Selected Soil Properties. Crop Manag. 2010, 9, 1. [CrossRef]

7. Phillips, W.A.; Coleman, S.A. Productivity and economic return of three warm-season grass stocker systems of the southern Great Plains. J. Prod. Agric. 1995, 8, 334-339. [CrossRef]

8. Fieser, B.G.; Horn, G.W.; Edwards, J.T.; Krenzer, J.E.G. Timing of grazing termination in dual-purpose winter wheat enterprises. Prof. Anim. Sci. 2006, 22, 210-216.

9. Baath, G.S.; Northup, B.K.; Rocateli, A.C.; Gowda, P.H.; Neel, J.P.S. Forage potential of summer annual grain legumes in the southern great plains. Agron. J. 2018, in press.

10. Baath, G.S.; Northup, B.K.; Gowda, P.H.; Turner, K.E.; Rocateli, A.C. Mothbean: A potential summer crop for the Southern Great Plains. Am. J. Plant Sci. 2018, 9, 1391-1402. [CrossRef]

11. Rao, S.C.; Northup, B.K. Capabilities of four novel warm-season legumes in the southern Great Plains: Biomass and forage quality. Crop Sci. 2009, 49, 1096-1102. [CrossRef]

12. Rao, S.C.; Northup, B.K. Pigeon pea potential for summer grazing in the southern Great Plains. Agron. J. 2012, 104, 199-203. [CrossRef]

13. Rao, S.C.; Northup, B.K. Biomass production and quality of Indian-origin forage Guar in Southern Great Plains. Agron. J. 2013, 105, 945-950. [CrossRef] 
14. Butler, T.J.; Muir, J.P. Perspective on forage legume systems for tallgrass and mixed-grass prairies of the southern Great Plains of Texas and Oklahoma. Crop Sci. 2012, 52, 1971-1979. [CrossRef]

15. Northup, B.K.; Rao, S.C. Effects of legume green manures on non-grain biomass of continuous wheat systems. Agron J. 2016, 108, 1011-1108. [CrossRef]

16. Rao, S.C.; Northup, B.K.; Phillips, W.A.; Mayeux, H.S. Interseeding novel cool-season annual legumes to improve bermudagrass paddocks. Crop Sci. 2007, 47, 168-173. [CrossRef]

17. Upadhyaya, H.D.; Sarma, N.D.R.K.; Ravishankar, C.R.; Albrecht, T.; Narasimhudu, Y.; Singh, S.K.; Wanyera, N. Developing a mini-core collection in finger millet using multilocation data. Crop Sci. 2010, 50, 1924-1931. [CrossRef]

18. Joshi, M. Textbook of Field Crops; PHI Learning Private Limited: Delhi, India, 2015; pp. 75-84.

19. Irrigation. 2006. Available online: http://www.ikisan.com/irrigation.html (accessed on 9 September 2018).

20. Satish, L.; Rathinapriya, P.; Rency, A.S.; Ceasar, S.A.; Prathibha, M.; Pandian, S.; Ramesh, M. Effect of salinity stress on finger millet (Eleusine coracana (L.) Gaertn): Histochemical and morphological analysis of coleoptile and coleorhizae. Flora 2016, 222, 111-120. [CrossRef]

21. Singh, P.; Raghuvanshi, R.S. Finger millet for food and nutritional security. Afr. J. Food Sci. 2012, 6, 77-84.

22. Shobana, S.; Krishnaswamy, K.; Sudha, V.; Malleshi, N.G.; Anjana, R.M.; Palaniappan, L.; Mohan, V. Finger millet (Ragi, Eleusine coracana L.): A review of its nutritional properties, processing, and plausible health benefits. Adv. Food Nutr. Res. 2013, 69, 1-39. [PubMed]

23. National Research Council. Lost Crops of Africa: Volume I: Grains; National Academy Press: Washington, DC, USA, 1996.

24. Kumari, P.L.; Sumathi, S. Effect of consumption of finger millet on hyperglycemia in non-insulin dependent diabetes mellitus (NIDDM) subjects. Plant Foods Hum. Nutr. 2002, 57, 205-213. [CrossRef]

25. Devi, P.B.; Vijayabharathi, R.; Sathyabama, S.; Malleshi, N.G.; Priyadarisini, V.B. Health benefits of finger millet (Eleusine coracana L.) polyphenols and dietary fiber: A review. J. Food Sci. Technol. 2014, 51, 1021-1040. [CrossRef] [PubMed]

26. Gowda, P.H.; Prasad, P.V.; Angadi, S.V.; Rangappa, U.M.; Wagle, P. Finger millet: An alternative crop for the Southern High Plains. Am. J. Plant Sci. 2015, 6, 2686-2691. [CrossRef]

27. USDA-NRCS. Soil Survey of Canadian County, Oklahoma; Supplement Manuscript; USDA-NRCS and Oklahoma Agric. Exp. Stn.: Stillwater, MT, USA, 1999.

28. Hoffman, P.C.; Shaver, R.D.; Combs, D.K.; Undersander, D.J.; Bauman, L.M.; Seeger, T.K. Understanding NDF digestibility of forages. Focus Forage 2001, 3, 1-3.

29. SAS Institute. Base SAS 9.4 Procedure Guide: Statistical Procedures; SAS Inst.: Cary, NC, USA, 2017.

30. Steel, R.G.D.; Torrie, J.H. Principles and Procedures of Statistics: A Biometrical Approach, 2nd ed.; McGraw-Hill: New York, NY, USA, 1980.

31. Coleman, S.W.; Rao, S.C.; Volesky, J.D.; Phillips, W.A. Growth and nutritive value of perennial $C_{3}$ grasses in the southern Great Plains. Crop Sci. 2010, 50, 1070-1078. [CrossRef]

32. Oba, M.; Allen, M.S. Evaluation of the importance of the digestibility of neutral detergent fiber from forage: Effects on dry matter intake and milk yield of dairy cows. J. Dairy Sci. 1999, 82, 589-596. [CrossRef]

33. Starks, P.J.; Zhao, D.; Phillips, W.A.; Coleman, S.W. Development of canopy reflectance algorithms for real-time prediction of bermudagrass pasture biomass and nutritive values. Crop Sci. 2006, 46, 927-934. [CrossRef]

34. Ackerman, C.J.; Purvis, H.T.; Horn, G.W.; Paisley, S.I.; Reuter, R.R.; Bodine, T.N. Performance of light vs heavy steers grazing Plains Old World bluestem at three stocking rates. J. Anim. Sci. 2001, 79, 493-499. [CrossRef] [PubMed]

(C) 2018 by the authors. Licensee MDPI, Basel, Switzerland. This article is an open access article distributed under the terms and conditions of the Creative Commons Attribution (CC BY) license (http:/ / creativecommons.org/licenses/by/4.0/). 